\title{
Creative Drama As A Teaching Tool in The Classroom
}

\section{Syarul Azlina, Muhammad Faisal Ahmad, Zolkipli Abdullah}

To Link this Article: http://dx.doi.org/10.6007/IJARBSS/v11-i3/8912

DOI:10.6007/IJARBSS/v11-i3/8912

Received: 01 January 2021, Revised: 27 January 2021, Accepted: 17 February 2021

Published Online: 11 March 2021

In-Text Citation: (Azlina et al., 2021)

To Cite this Article: Azlina, S., Ahmad, M. F., \& Abdullah, Z. (2021). Creative Drama As A Teaching Tool in The Classroom. International Journal of Academic Research in Business and Social Sciences, 11(3), 1-6.

\section{Copyright: @ 2021 The Author(s)}

Published by Human Resource Management Academic Research Society (www.hrmars.com)

This article is published under the Creative Commons Attribution (CC BY 4.0) license. Anyone may reproduce, distribute, translate and create derivative works of this article (for both commercial and non-commercial purposes), subject to full attribution to the original publication and authors. The full terms of this license may be seen at: http://creativecommons.org/licences/by/4.0/legalcode

Vol. 11, No. 3, 2021, Pg. 1 - 6

Full Terms \& Conditions of access and use can be found at http://hrmars.com/index.php/pages/detail/publication-ethics 


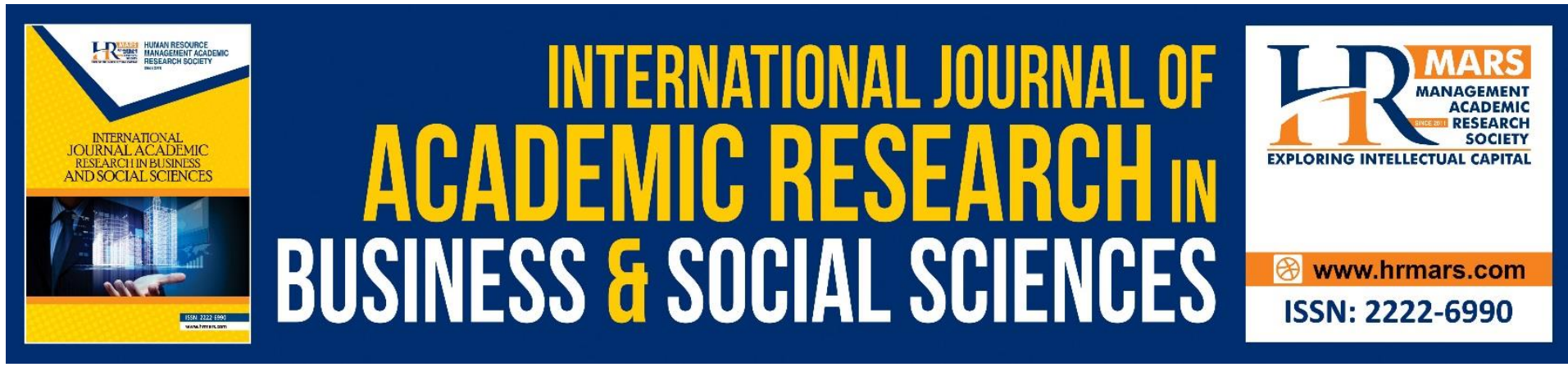

\title{
Creative Drama As A Teaching Tool in The Classroom
}

\author{
Syarul Azlina \\ Faculty of Film, Theatre And Animation, Universiti Teknologi MARA, Selangor Branch \\ Muhammad Faisal Ahmad, Zolkipli Abdullah \\ Faculty of Music and Performing Arts, Sultan Idris Education University, Malaysia
}

\begin{abstract}
Previous studies revealed that creative drama has its own advantage in terms of education. In this study, creative drama has been implemented to prove that it has its own role as a teaching tool in the classroom. A qualitative research design was used and data was collected from 10 children as samples in the District of Rawang, Selangor. This study used questionnaire and continuous record as instruments. The study was carried out for two weeks. In this study, the use of creative drama as a teaching tool was found to hold influence over comprehension and behaviour of children in the classroom. It can therefore be concluded that creative drama has a significant role as a teaching tool in the classroom.
\end{abstract}

Keywords: Creative Drama, Tool, Classroom.

\section{Introduction}

According to Vera Mowry Roberts, the study of the theatre is considered to be the most ideal and liberalizing of all liberal arts. Theatre takes the student into many areas of human knowledge including literature, art, music, politics, economics, philosophy, science and invention that practically explores all of man's activities and ideas. Creative drama, a field of theatre. Covers playmaking, process drama and also improvisation. As the term playmaking implies, the activity goes beyond dramatic play in scope and intent. Dialogue is created by the players, whether the content is taken from a well-known story or is an original plot. The word drama is used to mean "literature". The term creative drama is used to describe the improvised drama of children from the ages of five or six and older, but it belongs to no particular age level and may be used just as appropriately to describe the improvisation. Creative drama is also described to be more structured, spontaneous and the players are free to do improvisation at any time.

Next, creative drama is shaped whenever theatre is able to arouse the child's imagination and place him or her in a special situation using improvisation and free narration so that the participant can express himself. According to Freud, "creative thought is the highest form of free thoughts and childhood games". In this process, children use their imagination firstly to encourage an imaginative world which is analogous to their real experiences and they can 
perform it. Freud believes that the roots of creativity are found in childhood experiences and for the form of these childhood experiences is utterly effective in the emergence of new thought. Creative drama is helps children to boost their creativity and is the reason as to why it makes special use of theatre in schools and educational institutions. Furthermore, creative drama can act as a new and effective tool in the educational system and also it does not require extra facilities.

Therefore, creative drama can be used widely by teachers as one of the teaching tools. This is because there are a few important values that can be gained from creative drama such as creativity and development, understanding and appreciation of the cultural backgrounds and values of others. These values would help children to deepen their understanding and experience on creativity and appreciation.

\section{Objectives}

The study aims to identify the comprehension and behaviour of children with the use of creative drama as a teaching tool. The research design used was qualitative method based on the observation method. The researcher used instruments such as questionnaire and also personal interviews. This method was chosen as the study examined and identified the comprehension and types of emotions of children by using creative drama as a teaching tool. The selected pre-school is located in the district of Rawang, Selangor whereby researchers have prior experience.

The selected sample involved 10 pre-school children ( 5 boys and 5 girls) aged between 5 to 6 years old. Activities were conducted as part of the research whereby creative drama was implemented using a short story entitled" The Shepherd Boy and the Wolf" to identify the comprehension of the story that was presented. Situational activities (in a restaurant and library) based on creative drama were also conducted. Thus, each of the activities both required the children to role play by pretending to be in character.

Then a questionnaire was provided to the children whereby the data collected was analysed and collated in the form of a bar graph. There were a few items that were included in the questionnaire to help the researcher to identify the comprehension of children through the use of creative drama as a teaching tool.

\section{Findings}

10 children were selected as samples in this research. The short story that used for this analysis is "The Shepherd Boy and the Wolf". The instruments that was used is a questionnaire that observed the comprehension of the children. The result of the analysis is listed below: 


\begin{tabular}{|c|c|c|c|c|}
\hline No of question & Poor & Medium & Good & Excellent \\
\hline $\begin{array}{l}\text { 1. Who are the characters } \\
\text { in the story? }\end{array}$ & - & $30 \%$ & $60 \%$ & $10 \%$ \\
\hline $\begin{array}{l}\text { 2. When and where did the } \\
\text { story take place? }\end{array}$ & - & $60 \%$ & $30 \%$ & $10 \%$ \\
\hline $\begin{array}{l}\text { 3. What happens to the } \\
\text { characters in the story? }\end{array}$ & - & $40 \%$ & $50 \%$ & $10 \%$ \\
\hline $\begin{array}{l}\text { 4. How does the character } \\
\text { solve his/her problem? }\end{array}$ & - & $50 \%$ & $50 \%$ & - \\
\hline $\begin{array}{l}\text { 5. What is the ending of the } \\
\text { story? }\end{array}$ & - & $40 \%$ & $50 \%$ & $10 \%$ \\
\hline $\begin{array}{l}\text { 6. If you are the character } \\
\text { in the story, what will you } \\
\text { do? }\end{array}$ & - & $50 \%$ & $40 \%$ & $10 \%$ \\
\hline
\end{tabular}

Table 1

Table 1 shows the analysis of the comprehension of children with the use of creative drama as a teaching tool. Based on the first question, the highest percentage of $60 \%$ is recorded at a 'good' scale. This shows that the children have adequate understanding about the character in the story. The second question shows that the medium scale have the significant data for the question 2 which is at $60 \%$. This means that the children do not really understand and are not able to determine when and where the story takes place. Next, the third question had recorded the highest percentage at the good scale which is at $50 \%$. This means that the children were able to identify what really happened to the character in the story. Other than that, the fourth question consists of $50 \%$ for medium scale and also $50 \%$ for good scale. Next, the highest percentage in the fifth question is at the good scale which $50 \%$. This means that the children were able to state the ending of the story. Lastly, sixth question recorded the highest percentage at the medium scale which is at $50 \%$. The children were able to state would happen if he or she were to be one of the character of the story.

\section{Activity 1: Creative Drama with Situation at a Restaurant}

Table 2 shows that the types of children's behaviour based on the creative drama with a situation at a restaurant. The highest percentage recorded was $80 \%$ of having fun with the activity. The children were happy, cooperated with each other and easily laughed during the activity. While the behaviour pattern of actively participating and talking excessively shared the same percentage, at $70 \%$. The children seemed to enjoy themselves, cooperated with each other, easily able to laugh, able to communicate with their friends and able to show their body language during the activity. Lastly, the percentage of shy or timid pupils was at $30 \%$. The research helped the children who were shy or timid by enabling them to join the other children to do the dramatic play of a situation in a restaurant. 


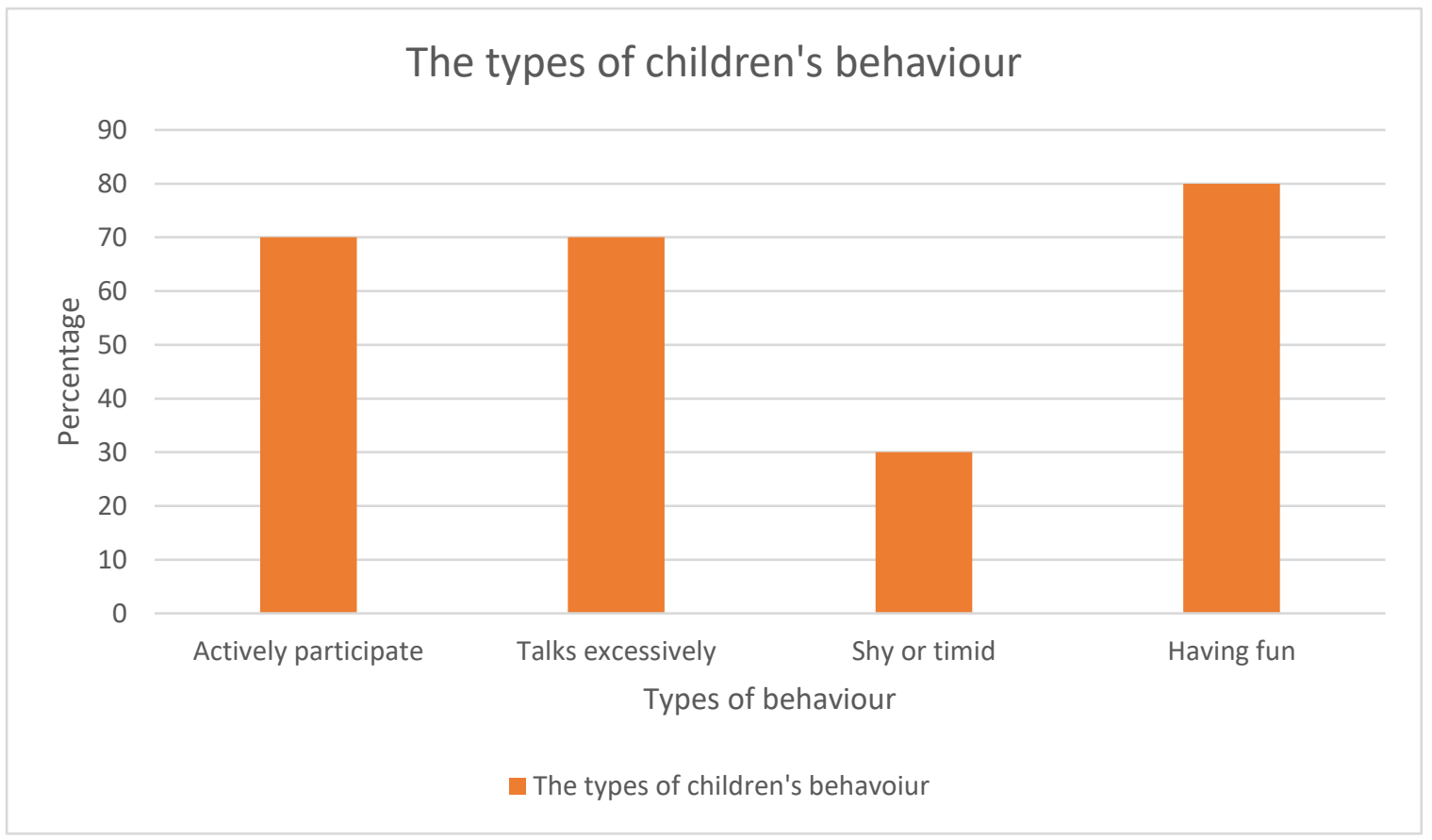

Table 2

\section{Activity 2: Creative Drama of a Situation in a Library}

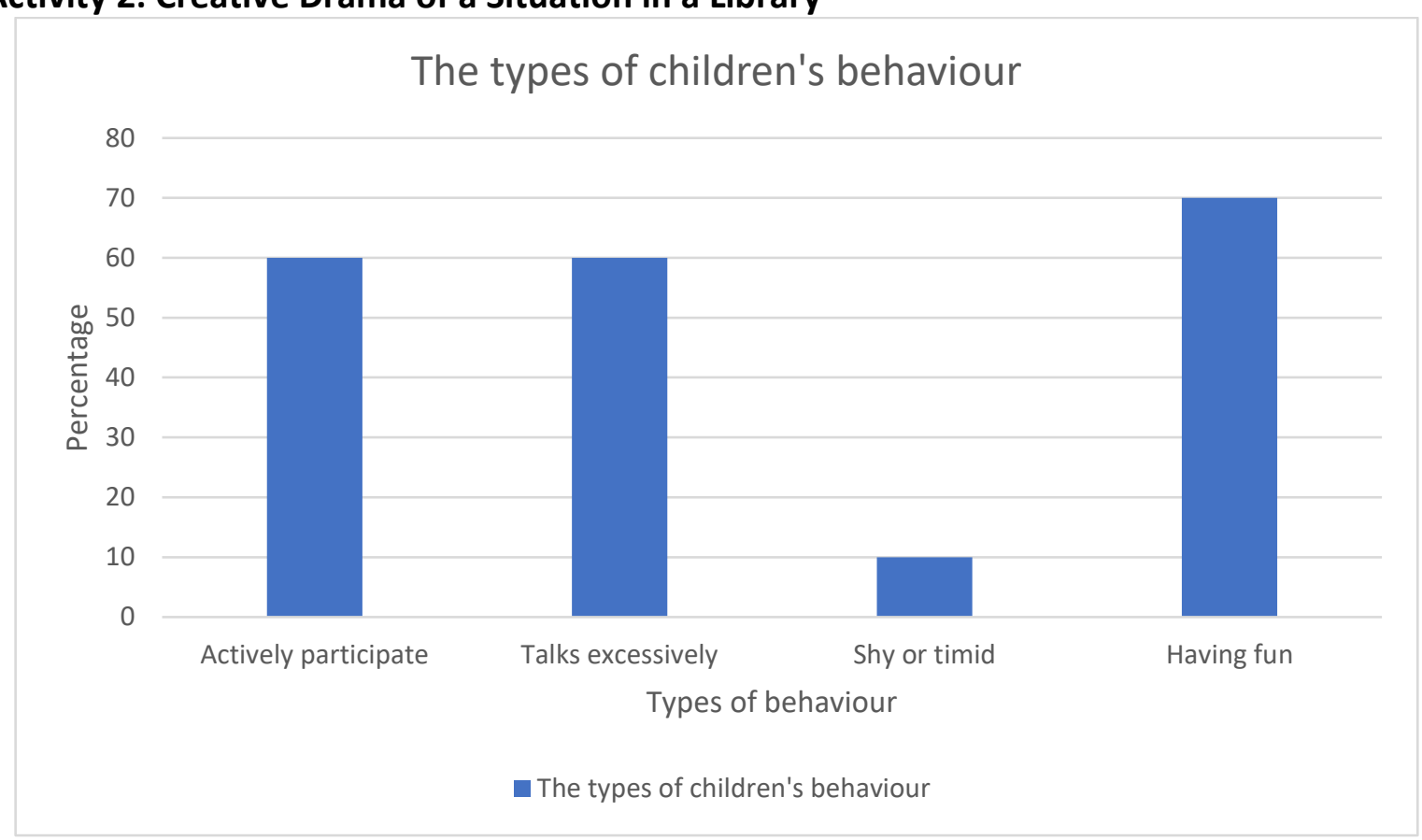

Table 3

Table 3 shows that the types of children's behaviour based on the creative drama of a situation in a library. The highest percentage recorded was of the children having fun which was at $70 \%$. The children exhibited a nature of helping each other during the activity. While the behaviour of actively participating and talking excessively shared the same percentage which was at $60 \%$. The children seemed to enjoy themselves, cooperated with each other, able to laugh easily and able to communicate with their friends while exhibiting body language during the activity. Lastly, percentage of children who were shy or timid was only 
recorded at $20 \%$. Thus, this shows that the children were having fun with creative drama that was implemented in the classroom.

\section{Conclusion}

The conclusion is that creative drama is able to the children to be involved as well as allow them to express themselves emotionally but also intellectually, physically, verbally and socially. As players in creative drama, children need to assume the roles of others and they learn about and become sensitive to the problems and values of persons who are different from themselves. At the same time, they are learning how to work cooperatively, communicate effectively and also on how to help each other out. In the process of creative drama, children, who inherently possess creative and impudent minds, may be able to find a chance to display their creativity. This is because many psychologists believe that creativity shows itself in the first few years of a child's life. They also believe that this creativity comes together with imagination. Creative drama also helps to improve learning to be more active and the students are easily engaged and involved in the learning process. Thus, creative drama has a significant role as one of the teaching tools that can be conducted in the classroom.

\section{Acknowledgement}

Deep appreciation and gratification for Faculty Of Film, Theatre And Animation Universiti Teknologi MARA, Selangor Branch and Faculty of Music and Performing Arts, Sultan Idris Education University and several individuals involved in data contribution throughout the in completing this research.

\section{Corresponding Authors}

Syarul Azlina binti Sikandar

Faculty Of Film, Theatre And Animation Universiti Teknologi MARA, Selangor Branch 40150 Puncak Perdana Selangor, Malaysia

Email: Syarul364@uitm.edu.my

\section{References}

Anna, L., Kaasinen, M., Karjalainen, M. V., \& Tapio, T. (2016). Promoting creativity in teaching drama. University of Helsinki: Finland.

Wilson, A., Scanlon, J. (2004).Supporting reading. Great Britain: David Fulton Publishers.

Ladousse, G. P. (1987). Role play. Oxford: Oxford University Press.

Lin. (2011). Fostering creativity through education - a conceptual framework of creative pedagogy.Creative Education, 2(3)

Momeni, S., Khaki, M., \& Amini, R. (2017). The role of creative drama in improving the creativity of 4-6 years old children. Journal of History Culture and Art Research.

Rasmussen, B. (2010). The 'good enough' drama: reinterpreting constructivist aesthetics and epistemology in drama education. Research in Drama Education: The Journal of Applied Theatre and Performance.

The National Curriculum Board of Education. (2016). The core curriculum for basic education 2016. Ministry of Education and Culture. 